\title{
MARCIN LISAK \\ Religijność a tożsamość narodowa. Polscy katolicy na emigracji w Irlandii i Wielkiej Brytanii
}

Związek religijności z kulturą jest niewątpliwie jednym $\mathrm{z}$ istotnych wymiarów życia społecznego oraz czynników oddziałujących na jednostkę w trakcie procesu socjalizacji. W przypadku społeczeństwa polskiego związek ten stereotypowo określany jest jako zbitka pojęciowa: Polak-katolik. Oczywiście to stereotypowe założenie nie uwzględnia różnorodności wyznaniowej, która co prawda dziś w Polsce jest niewielka, ale dawniej była znaczącym elementem pejzażu społecznego w tolerancyjnej i ekumenicznej I Rzeczypospolitej. Tak czy inaczej, w niniejszym opracowaniu zajmujemy się liczną częścią polskiego społeczeństwa, która przyznaje się do katolickiej przynależności. Choć jednocześnie nie oznacza to, że każdy przedstawiciel polskiej narodowości jest osobą mocno związaną z religijnością instytucjonalną albo sprywatyzowaną.

Artykuł podejmuje analizę zachowań, postaw i poglądów współczesnej, nowej fali polskich emigrantów mieszkających w Irlandii i Wielkiej Brytanii. Jego celem jest rekonstrukcja specyfiki polskiego katolicyzmu, jaki uwydatnia się w sytuacji emigracji. W badaniach posłużono się metodami jakościowymi: analizą częściowo ustrukturyzowanych wywiadów oraz obserwacją uczestniczącą. Myślą przewodnia projektu badawczego było rozpoznanie problemów emigracyjnego życia polskich katolików przybyłych na początku XXI w. do Irlandii i Wielkiej Brytanii. Ich tożsamość religijna widziana jest pod kątem kultury etnicznej. Badacze przeprowadzili 70 rozmów z wybranymi przedstawicielami polskich katolików-emigrantów oraz brytyjskich i irlandzkich katolików. W wytypowanych środowiskach rozmówcami byli zarówno katolicy świeccy, jak i duszpasterze oraz przedstawiciele wyższej hierarchii duchownej: polskiej, angielskiej, szkockiej i irlandzkiej. Projekt badawczy, zatytułowany: Polish Priests and Polish Parishioners in Great Britain and Ireland: Identifying Problems and Possibilities 
zrealizowano dzięki wsparciu lodyńskiego Porticus UK (dawniej: Derwent Consultancy $)^{1}$. Zbieranie materiałów w terenie i ich wstępne opracowywanie trwało od listopada 2008 do maja 2009 r.

\section{I. Środowisko badań}

Rozmówcy zostali dobrani celowo spośród jednostek typowych, czyli uczestników nabożeństw w katolickich kościołach. Na potrzeby niniejszego artykułu dokonałem analizy wypowiedzi uzyskanych od osób świeckich. Jednocześnie, z uwagi na ograniczoną objętość pracy, prezentacja i analiza wypowiedzi respondentów będą stosownie ograniczone do polskich emigrantów oraz irlandzkich i angielskich katolików (z pominięciem środowiska religijnego Szkocji).

Bierzemy zatem pod uwagę kilka środowisk badań. Na terenie Irlandii rozmówcami byli Polacy i Irlandczycy z irlandzkiej parafii St. Saviour's w centrum Dublina. W tym kościele od lutego 2006 r. funkcjonuje regularne duszpasterstwo dla Polaków. W ramach projektu badawczego uzyskano transkrypcję 10 wywiadów z Polakami oraz 8 z Irlandczykami. Rozmówcami na terenie Wielkiej Brytanii były osoby związane z duszpasterstwami w Boston i Lincoln (Lincolnshire, środkowa Anglia, archidiecezja Nottingham) oraz kilku miejsc w Londynie ${ }^{2}$. Na tych terenach w Anglii funkcjonuje silnie zakorzenione duszpasterstwo dla Polaków prowadzone przez Polską Misję Katolicka. Na terenie Anglii i Walii polscy katolicy w wielu miejscach dysponują własnymi kościołami. Jednak na potrzeby badań dobrano brytyjskie parafie, gdzie dodatkowo odprawiane są nabożeństwa w języku polskim, a polscy duszpasterze nie mieszkają ani nie pracują przy tych kościołach na stałe. Dzięki takiemu doborowi będziemy mogli przeanalizować także wypowiedzi rodzimych katolików, którzy są częścią społeczności przyjmującej polskich emigrantów.

Jeśli chodzi o socjo-demograficzną charakterystykę polskiej emigracji zagranicznej na początku XXI w., to ma ona zdaniem wielu ekspertów zdecydowa-

${ }^{1}$ Projekt badawczy prowadzony przez szkocki University of Aberdeen. Kierownik projektu prof. C la ire Walla ce, zespół: prof. Hali ina Grzy mała-Moszczyńska, dr David Hay, dr Marta Trzebiatowska, Joanna Krotofil, Anna Jurek, dr Marcin L is a k. Fundatorem grantu badawczego jest Porticus UK (dawniej: The Derwent Charitable Consultancy) w Londynie.

${ }^{2} \mathrm{~W}$ dalszej części artykułu prezentowane są wypowiedzi respondentów. Rozmówcy mieszkają w różnych środowiskach a ich wypowiedzi zostały zakodowane. Pierwsza litera kodu oznacza narodowość: P - Polak, I - Irlandczyk, E - Anglik. Na drugim miejscu pojawia się określenie, gdzie przeprowadzono wywiad. Konsekwentnie zatem: D oznacza Dublin, N - Lincoln, Boston w diec. Nottingham, L - Londyn. W przypadku Londynu mamy do czynienia z osobami związanymi $\mathrm{z}$ angielskimi kościołami parafialnymi w Finchley, Highgate, South Kensington i Wimbledon, jednak nie rozróżniamy tej specyfiki. Trzecia litera kodu określa płeć respondenta: $\mathrm{K}$ - kobieta, $\mathrm{M}$ - mężczyzna. Liczba na końcu kodu oznacza wiek (albo przybliżony wiek) rozmówcy. 
nie zarobkowy charakter ${ }^{3}$. Odpływ migrantów z Polski nasilił się szczególnie po akcesji Polski do struktur Unii Europejskiej 1 maja 2004 r. Wedle szacunków Głównego Urzędu Statystycznego w końcu 2007 r. łącznie poza granicami Polski, przynajmniej na emigracji czasowej (ponad 3 miesięcznej), przebywało 2,27 mln osób. Najwięcej z nich przebywało w krajach $\mathrm{UE}^{4}$, przy czym szacunkowo w Wielkiej Brytanii 690 tys., w Niemczech 490 tys., a w Irlandii 200 tys. (na około 4,2 mln mieszkańców tego kraju). Dzięki bardziej dokładnym estymacjom wiemy, że liczba Polaków mieszkających po akcesji unijnej w Królestwie Brytyjskim wyraźnie wzrosła. Wedle oficjalnych statystyk brytyjskich Polacy stali się największą grupą narodową wśród obcokrajowców, wyprzedzając Irlandczyków i Hindusów. W roku 2007 co siódmy obcokrajowiec na brytyjskim rynku pracy był Polakiem ${ }^{5}$. Od 1 maja 2004 do końca 2008 r. w Wielkiej Brytanii zarejestrowało się oficjalnie 550 tys. polskich pracowników. Natomiast ostrożne zbiorcze oszacowania wskazują, że po akcesji wyjechało z Polski $1,1 \mathrm{mln}$. osób, w tym $94 \% \mathrm{w}$ wieku produkcyjnym (15-59 lat $)^{6}$.

Z kolei na terenie Irlandii od 2002 do 2007 r. liczebność polskich emigrantów wzrosła stukrotnie ${ }^{7}$. W tym przypadku w 2006 r. Polacy stanowili, wedle oficjalnych, choć nieprecyzyjnych statystyk demograficznych, 1,5\% ogółu mieszkańców Republiki Irlandzkiej ${ }^{8}$. Z uwagi na brak wymogów rejestracyjnych wielkości polskiej kohorty etnicznej na terenie Irlandii nie sposób jednak dokładnie oszacować. Dane oparte na statystykach rządowych wskazują na wyraźne zatrzymanie napływu Polaków. Nie ma jednak przekonujących badań, które potwierdzałby medialne doniesienia o masowym wyjeździe polskich emigrantów, mających rzekomo w ogromnej liczbie wracać do Polski. Dość powiedzieć, że od 1 maja 2004 r. do końca lipca 2009 państwowy numer ewidencyjno-podatkowosocjalny (tzw. PPSN) otrzymało aż 316.082 obywateli polskiej narodowości ${ }^{9}$. Jeśli uwzględnimy badania potwierdzające, że około $2 / 3$ spośród wydanych obcokrajowcom numerów PPSN jest nadal aktywnych w Irlandii ${ }^{10}$, to ciagle około

${ }^{3}$ Por. P. K a c z ma r z y k: Migracje zarobkowe Polaków $w$ dobie przemian. Warszawa 2006; K. R o m a n i s z y n: Rzecz o pracy i konsumpcji. Analiza antropologiczna. Kraków 2007.

${ }^{4}$ Por. K. I g 1 i c k a: Kontrasty migracyjne Polski. Wymiar transatlantycki. Warszawa 2008.

${ }^{5}$ Por. I. Grabow ska-Lu s ińska, M. Okó lski: Emigracja ostatnia?. Warszawa 2009 s. 67.

${ }^{6}$ Tamże, s. $74-75$.

${ }^{7}$ Tamże, s. 82-84.

${ }^{8}$ Por. Central Statistics Office Ireland: Census 2006 Report. Cork 2006 [http://www.cso.ie/ census/Census2006Results.htm (01.10.2009)].

${ }^{9}$ Por. Personal Public Service Number-Statistics on Numbers Issued. Department of Social and Family Affairs. Ireland [http://www.welfare.ie/EN/Topics/PPSN/Pages/ppsstat.aspx - 1 paźdz. 2009].

${ }^{10}$ Por. K. Kropiwi e c, R. C. K ing-O'R i a in: Polish Migrant Workers in Ireland. Maynooth: Department of Sociology. National University of Ireland. National Consultative Committee on Racism and Interculturalism 2008 s. 11. 
200 tys. Polaków może tam mieszkać (wobec całkowitej populacji na poziomie 4.459 tys. w kwietniu 2009) ${ }^{11}$.

\section{Spotkania kulturowe}

Wielu socjologów podkreśla charakterystyczny związek polskiej religijności, zwłaszcza katolicyzmu, z polską kulturą. Elementy obrzędowości religijnej stały się przez wieki pewną oczywistością kulturową, niemalże nieodzownym wymiarem etosu polskości. Wpływa to z jednej strony na bardzo wysoki poziom autoidentyfikacji religijnej, w tym przede wszystkim katolickiej ${ }^{12}$. Ludzie nie identyfikujący się z wiarą religijna, szerokie spektrum zdeklarowanych ateistów, agnostyków, osób indyferentnych religijnie może, jak słusznie podkreślają Krzemiński i Śpiewak, czuć się mniejszościq otoczonq niezbyt sobie życzliwym światem ${ }^{13}$.

Identyfikacja religijna: chrześcijańska, katolicka, a zarazem polska jest podtrzymywana między innymi przez uczestnictwo w nabożeństwach w języku polskim. Etniczne duszpasterstwo polskich emigrantów na Wyspach cechuje, zarówno w założeniach jak i w oczekiwaniach, chęć podtrzymania polskiego modelu katolicyzmu. Szczególnie na terenie tradycyjnie katolickiej Irlandii, Polacy nie mieliby żadnych trudności z odnalezieniem katolickich wspólnot i świątyń, które można spotkać na każdym kroku. Również na terenie Wielkiej Brytanii rozwinięta jest sieć katolickich parafii, choć $\mathrm{z}$ racji historycznych jest ona zdecydowanie szczuplejsza od irlandzkiej. W wielu regionach Wysp Brytyjskich polskie duszpasterstwo zapewnione jest także w wyodrębnionych kościołach prowadzonych przez Polską Misję Katolicką. Dla celów porównawczych wybraliśmy jednak takie miejsca, gdzie polscy katolicy korzystają z gościnności lokalnych brytyjskich wspólnot i kościołów katolickich.

Osoby, z którymi przeprowadziliśmy wywiady, zarówno w Irlandii jak i w Wielkiej Brytanii, zgodnie wskazywały na potrzebę istnienia polskojęzycznego duszpasterstwa:

Chodzę rzadziej, przez pierwsze lata pobytu nie było tu polskiego duszpasterstwa, a ja nie znam angielskiego wystarczająco (DK34).

\footnotetext{
${ }^{11}$ Por. Central Statistics Office Ireland. Population and Migration Estimates April 2009, Dublin-Cork 22.09.2009 s. 1.

12 Por. E. Nowicka: Roman Catholicism and the Contents of »Polishnes». W: I. B or ow i k, G. B a b ińsk i (eds.): New Religious Phenomena in Central and Eastern Europe (81-92), Kraków 1997 s. 81.

${ }^{13}$ I. K r z e m i ń s k i, P. Ś p i e w a k: Druga rewolucja w matym mieście. Zmiana ustrojowa w oczach mieszkańców Mławy i Szczecinka. Warszawa 2001 s. 70.
} 
Preferencja dla „polskich” mszy wynika jednak nie tylko z przyczyn językowych. Wielu rozmówców podkreśla szczególną specyfikę i znaczenie mszy w języku polskim:

Msze [polskie] są odprawiane tak bardziej uroczyście. Mamy też zwyczaje świąteczne: pokarmy na Wielkanoc, żłobek i choinkę, pieśni kościelne. U Irlandczyków, jak byłem kilka razy, jest tak bardziej sucho. Mniej się na mszy działo. Wszystko trwało krócej. Choć na przykład ksiądz wychodził na koniec przed kościół i żegnał się z ludźmi (PDM32).

Angielski to nie jest dla mnie wielki problem. Ale tu są pewne różnice. Dla mnie polskie msze są bardziej zrozumiałe, takie tradycyjne (PDM32). ściele:

Podkreślają to także ci, którzy rzadko pojawiają się na nabożeństwach w ko-

To jest inna różnica niż język. Jeżeli już pojawiam się w kościele, to na przykład dlatego, żeby poczuć polskie święta (PDK25).

Wyjątkowość modlitwy w języku ojczystym zrozumiała jest też dla niektórych irlandzkich rozmówców:

Język jest sprawą kluczową. Zawsze się modlimy w swoim własnym języku. Sam tak robiłem, jak przez kilka lat mieszkałem we Francji (...). Naturalne jest zatem, że Polacy chcą modlić się w kościele po polsku (IDM40+).

Rzadko kiedy uczestnicy wywiadów zapowiadali, że w przypadku braku nabożeństw w języku polskim, bez problemów przystosują się do nabożeństw w języku angielskim.

Raz poszłam i nic nie zrozumiałam, jakoś nie czułam się tam swojsko. Wolę jednak tam polską mszę, ze względu, że to jest po polsku (PNK30+).

Zdarzają się jednak całkiem odrębne deklaracje, potwierdzające, że część polskich emigrantów partycypuje w irlandzkim duszpasterstwie parafialnym:

W niedzielę tak, ale czasami też w tygodniu, kiedy przechodzę koło kościoła i jest msza po angielsku to na nią idę. Czasami w niedzielę chodzę na msze po angielsku, jak godzina mi lepiej pasuje (PDM30).

Odpowiedzi na pytanie o zachowywanie polskich zwyczajów przynosiło niemal identyczne odpowiedzi. Elementem polskiej tradycji, akcentowanym przez emigrantów, były przede wszystkim święta kościelne i zwyczaje religijne oraz polskie potrawy:

Na pewno Wielkanoc i Boże Narodzenie. Ale już na przykład Wszystkich Świętych i Dzień Zaduszny to nie. W domu jemy raczej polskie potrawy albo produkty. Za irlandzką 
kuchnią nie przepadam. Obchodzę imieniny i Dzień Matki wedle polskiego kalendarza (PDK34).

Jeśli chodzi o święta Bożego Narodzenia, to mieliśmy Wigilię, kolację wigilijną. Później w Święta mieliśmy obiad razem, i takie inne rożne rzeczy. Jeśli chodzi o Wielkanoc to spotkaliśmy się razem, byliśmy w kościele i czas spędzaliśmy razem na rozmowach, oglądaniu telewizji (PLK30).

Brytyjskie czy irlandzkie zwyczaje nie stają się zbyt popularne. Bywają oceniane jako nudne albo wręcz nie na miejscu. Przykładem jest Halloween Party, które kłóci się z polskimi obyczajami religijnymi:

I właśnie to nie ma dla mnie za bardzo sensu i kłóci się z moimi przekonaniami podobnie. Właśnie dlatego, że pierwszego listopada jest święto Wszystkich Świętych i ma to dla mnie bardziej pozytywne znaczenie, o zupełnie innej atmosferze. I jest to dla mnie po prostu nie do pogodzenia (PLK30).

Niektórzy przyjmują jednak zwyczaje miejscowe takie, jak wyrosłe na podłożu czasu oczekiwania na Boże Narodzenie, ale dziś zupełnie zeświecczone Christmas Party. Jedna z osób przyznaje się do zakłócenia w ten sposób „,polskiego" adwentu...

Może raz uczestniczyłam w tych Christmas Party, w Polsce tego nie ma, jest wtedy w Polsce taki post, wszystko jest stonowane, jest atmosfera spokoju, powagi. Natomiast tutaj, wszystko super, zabawa, śmiechy, no i ja uczestniczę w tych Christmas Party, bo zawsze sobie w pracy urządzamy. Też po to, by się w jakiś sposób zintegrować z pozostałymi pracownikami (PLK25).

Dochodzi jednak do tego, że wśród samych polskich katolików rysują się podziały w kwestii rozumienia, czym jest polska tradycja kościelna i narodowa:

[...] zwróciłem uwagę, bo mi się bardzo nie podobało, bo ludzie wykształceni, z wyższym wykształceniem, no tu mi chodzi o taką panią lekarkę i wielu innych, jak tu były takie czytania polskie, tłumaczą żeby kulturę i tradycje polską zachowywać, no ale jak podchodzą do Komunii to zamiast do ust, to oni wyciagają rękę, no gdzie tak, to oni się mylą z tym co mówią. To są błędne pojęcia, no jak w Polsce nie daje się komunii do ręki, tylko się bierze do ust, a ona mówi, żeby kulturę, tradycję polską, no to już się mija z sobą (PNM55).

Dokonując podsumowania kwestii kulturowej należy podkreślić, że emigranci potrzebują polskich nabożeństw. Po pierwsze, jest to niezbędne Polakom, którzy jeszcze dość słabo znają język angielski. Po drugie, polskie nabożeństwa są jednak na tyle istotnym nośnikiem tożsamości czy polskości, dają poczucie zrozumienia, akceptacji, przystosowania, podtrzymania tego, co bliskie, że wydają się nieodzowne dla emigrantów (nawet jeśli ci już dobrze opanowali język angielski). 
Możemy się więc zgodzić z tezą Mariańskiego, który przekonująco wskazuje, że religijność polska $w$ wymiarze autoidentyfikacjnym jest bardzo trwatym elementem kultury ${ }^{14}$. Kiedy spojrzymy na autodeklaracje religijne wyrażone w statystykach przynależności religijnej Głównego Urzędu Statystycznego, to odnotowano w nich wysoki poziom identyfikacji religijnej Polaków. Wedle danych z końca roku 2005, aż 90\% Polaków (34,22 mln) deklarowało przynależność do Kościoła katolickiego, a 1\% do Kościoła prawosławnego (0,51 mln). Jednak 3,1 mln (8\%) zaznaczyło brak przynależności wyznaniowej ${ }^{15}$. Dane te odbiegają zatem od uspokajających wskazań o wysokim poziomie przynależności religijnej. Przy czym, niższy poziom (o około 5\%) poczucia przynależności wyznaniowej w porównaniu do deklaracji religijności (bycia osobą wierząca, religijną przynajmniej w mały stopniu) potwierdza sam Mariański ${ }^{16}$. A zatem, w zbiorowości osób, które identyfikują same siebie jako niewierzące, spotkamy jednak Polaków pozostających $\mathrm{w}$ związku z religijnością kościelną. Może o tym decydować wiele czynników, takich jak motywy psychiczne, przywiązanie do tradycji rodziców, wychowawcze walory religii, ale także budowanie własnej tożsamości na gruncie wiary i wokół religijności ${ }^{17}$. Wówczas deklaracje pewnej formy przynależności instytucjonalnej $\mathrm{w}$ sferze religijności kościelnej poprzez osoby niewierzące, świadczą jeszcze mocniej o doniosłej roli religii w obrębie kultury.

Jednak z naszej perspektywy potwierdzenie zyskuje odwrotna zależność: powiązanie religijności z kulturą narodową ${ }^{18}$. W świetle wypowiedzi uczestników badania okazuje się, że zwyczaje i tradycje kultury narodowej są definiowane w niemal wyłączny sposób poprzez elementy religijne. Trudno jednak stwierdzić, że wskazywane zwyczaje są sensu stricte religijne, w rozumieniu esencjonalnym zjawiska religijności. Dają one wyraz raczej tożsamości i identyfikacji kulturowej respondentów. W takim przypadku mamy do czynienia z religijnością, która jest częścią kultury narodowej, lub, jak pisze o polskim przypadku N.

${ }^{14} \mathrm{~J}$. M a r i a ń s k i: Religijność społeczeństwa polskiego $w$ perspektywie europejskiej. Próba syntezy socjologicznej. Kraków 2004 s. 170.

${ }^{15}$ Na podstawie - Główny Urząd Statystyczny: Mały Rocznik Statystyczny. Warszawa 2007.

${ }^{16}$ Por. J. M a ri ań s k i, dz. cyt., s. 172-173.

${ }^{17}$ Por. C. D. B a s to n, P. S c h o e n r a d e, W. L. Vent i s: Religion and the individual: A social-psychological perspective. Oxford: Oxford University Press 1993 s. 87-102.

${ }^{18}$ Jest to zdanie przeciwnie wobec ustaleń wspomnianego socjologa, który w dalszej części wywodu stwierdza: Sondaże ogólnopolskie CBOS-u nie wskazywaty na odchodzenie $w$ latach dziewięćdziesiatych od religijności, a autodeklaracje wiary pozostawaty na zbliżonym poziomie. Około połowa badanych w 1989 roku Polaków określata siebie jako wierzqcych i regularnie praktykujacych, trzecia część jak wierzqcych i regularnie praktykujacych, dziesiata część jako wierzqcych ale niepraktykujacych, jedna setna jako niewierzqcych ale praktykujacych i jedna dwudziesta jako niewierzacych i niepraktykujacych. (...) Ten stan autoidentyfiakcji religijnych utrzymuje sie zasadniczo do dnia dzisiejszego - (J. M a r i a ń s k i, dz. cyt., s. 170). 
Demerath, religią kulturową ${ }^{19}$. Z drugiej strony, liczne zwyczaje i wartości kulturowe mają swoje religijne znaczenie, a przynajmniej religijną genezę. Widzimy, że wielu polskich emigrantów utożsamia święta i obyczaje religijne ze zwyczajami kulturowymi i wyrazem tożsamości etnicznej.

\section{Tożsamość religijna faktorem separacji}

Wypowiedzi angielskich rozmówców, w zdecydowanej większości osób zaangażowanych w działalność parafialną, bardzo często wskazują na doświadczenie separacji z polskimi katolikami. Odprawiane, głównie w niedziele, msze w języku polskim potęgują izolację polskich emigrantów:

Przypuszczam, że jest tu [przy kościele] także polska wspólnota. Oni mają oddzielne msze po polsku, albo po ukraińsku w niedzielne przedpołudnie. $\mathrm{W}$ ten sposób oni zmierzają do oddzielenia, separują się (ENK48).

Jednak nie tylko Polacy nie chodzą na angielskie msze:

Mamy też Ukraińców, którzy też nigdy nie chodzą na nasze msze. Przyjeżdża do nich ukraiński ksiądz i odprawia im msze, podobnie jak w przypadku Polaków (ENM50+).

W miejscach, w których nie ma kościoła „polskiego” Polacy korzystają (wynajmują) z lokalnego kościoła parafialnego. W określonym terminie odprawiane są tam nabożeństwa w języku polskim. Zwykle polski ksiądz dojeżdża w to miejsce, mając pod opieką kilka podobnych. Parafia angielska zazwyczaj oczekuje w takim przypadku pokrycia kosztów użytkowania świątyni.

$\mathrm{Na}$ tle opłat za wynajem kościoła pojawiają się napięcia. Z jednej strony Polacy czują się traktowani zbyt ,interesownie”. Uważają że mają prawo do modlitwy w kościele bez żadnych dodatkowych opłat, gdyż świątynia ma właśnie taką kultyczną funkcję. Niektórzy uskarżają się na to, że otrzymują zbyt mały dostęp do budynku sakralnego:

Żeby to był swój kościół, a nie wynajmowany, wtedy można by przychodzić tyle ile by się chciało (ENK30+).

Oczywiście kościół jest dla nich dostępny także poza polskimi nabożeństwami. Widocznie niektórym osobom brakuje szerszego zakresu wspólnych rytuałów kościelnych. W zdecydowanej większości nie przychodzą jednak na angielskie nabożeństwa i tradycyjnie organizowane po nich spotkania przy kawie i herbacie.

19 Por. N. J. D e me r a th III: The rise of »cultural religion « in European Christianity: Learning from Poland, Northern Ireland, and Sweden. „Social Compass”. R. 47: 2000 nr 1 s. 127139. 
Z kolei osoby udzielające się $\mathrm{w}$ jednej $\mathrm{z}$ angielskiej parafii podkreślają, że trudno od polskich katolików wyegzekwować pieniądze na pokrycie kosztów oświetlenia czy ogrzewania. Sytuacja taka ma miejsce szczególnie w przypadku, gdy polski ksiądz zabiera dla siebie ofiary złożone w kościele na tacę, nie przekazując nic parafii.

W angielskich parafiach, które są zarazem miejscem duszpasterstwa w języku polskim widzimy raczej separację pomiędzy rdzennymi parafianami a polskimi katolikami. Obie grupy narodowe właściwie nie spotykają się na gruncie kościelnym. Choć pewne zwyczaje można byłoby przyjąć w Anglii:

Jest tam jakieś grono ludzi, które się rozpoznaje i z którym utrzymuję jakiś tam kontakt, albo chodzę na pączki i herbatę. Bardzo lubię paczki i herbatę, i myślę że to jest fantastyczny pomysł, brytyjski oczywiście. W Polsce nie do wykonania jeśli wychodzi z kościoła 10 tys. ludzi, i każdy chce pączka i herbatę (ELM31).

Polscy uczestnicy angielskich nabożeństw czasami spotykają się z ostracyzmem ze strony pozostałej części polskiej społeczności:

Znam jedną młodą Polkę, Agnieszkę, która chodzi na msze po angielsku. Ale wiecie co jej powiedziano? „Ty zdradzasz Polaków, chodząc na msze razem z Anglikami”. Tak mi kiedyś powiedziała. Myślę, że to okropne słowa (ENM50+).

Wypowiedzi z wywiadów potwierdzają wnioski byłego katolickiego prymasa Anglii, kardynała Murphy C. O'Connor'a, który zauważył, że mimo znacznego napływu praktykujących polskich katolików wyraźnie brakuje integracji z lokalnymi brytyjskimi parafiami. Należy podejrzewać, że tendencje izolacjonistyczne są jeszcze silniejsze w ,polskich” kościołach prowadzonych na terenie Anglii przez Polską Misję Katolicką .

Procesy integracyjne są jednak zdecydowanie bardziej złożonym zjawiskiem niż prosta adaptacja do nowych warunków, czy też samoistna, albo nawet promowana przez instytucje i autorytety, asymilacja. W świetle wielu głosów wydaje się, że obie strony etnicznych dyferencjałów są świadome niedociagnięć procesu integracji. Jednocześnie jednak pojawiają się wypowiedzi zdystansowane wobec szybkiej integracji bądź asymilacji:

Na przykład mówił biskup G. [duchowny angielski], by się bratać itd., ale generalnie wydaje mi się, że wszystko dzieje się po prostu naturalnie, i że wszelkie właśnie integracje po prostu, które się dzieją w moim gronie na siłę po prostu niekoniecznie wypalają, a wręcz nie (...) taka totalna integracja, np. chodzenie do kościoła angielskiego tylko i wyłącznie, nie wydaje mi się do końca dobra i konieczna. Ponieważ są polscy księża i pol-

${ }^{20}$ Por. W. L u b ow i e cki: Powszechny $i$ apostolski ... czy polski?. „Tygodnik Powszechny". R. 2008 nr 6 [dostępny w: http://tygodnik2003-2007.onet.pl/1547,1467957,1,563268, dzial. html (01.10.2009)]. 
skie kościoły i są polskie msze święte praktycznie w bardzo wielu miejscach. Widocznie ma to jakieś znaczenie po prostu i nie jest to tylko powodem, że ludzie nie mówią po polsku tylko jest to jakaś jedność kulturowa. I ludzie czują się jak u siebie, czują się bardziej sobą (PLK30).

Dystans wobec sensowności szybkiej integracji czy asymilacji wyrażają także niektórzy Anglicy:

Integracja nie jest jak kawa rozpuszczalna, która się błyskawicznie rozpuszcza. Jeśli chcesz myśleć o integracji, potrzebujesz perspektywy 5- 5 lat i nie możesz tego wymuszać. To będzie przede wszystkim druga generacja Polaków, którzy będą już chodzić do angielskich szkół (ENM71).

W każdym razie, często w opinii angielskich i irlandzkich parafian polscy katolicy jawią się jako grupa odizolowana, odseparowana od reszty parafii poprzez polskie nabożeństwa i zwyczaje religijne. Jednocześnie Polacy są uprzywilejowani, gdyż jako niemalże jedyna grupa etniczna mają zapewnione kościelne nabożeństwa oraz inne formy posługi sakramentalnej w swoim ojczystym języku:

Nie sądzę, żeby byli [Polacy] połączeni, zintegrowani, ponieważ widuję ich tylko modlących się oddzielnie i chodzących do kościoła zupełnie innymi drogami. Może niektórzy są zintegrowani, ale niewielu (IDM36).

Polacy nie są prawdziwie zintegrowani. Mamy tu parafialne msze i oddzielne dla Polaków. Te wspólnoty się jednak nie mieszają ze sobą. Irlandzcy dominikanie opiekują się irlandzkimi parafianami, a polscy dominikanie zajmują się swoim rodakami i tyle (IDM70+).

Trzeba jednak podkreślić, że w świetle tej wypowiedzi brakuje przede wszystkim współpracy pomiędzy samymi duszpasterzami, którzy w pierwszym rzędzie decydują o wspólnych inicjatywach, a zarazem o zasięgu wymiany pomiędzy lokalną a napływową częścią społeczności parafialnej. Tymczasem we współdzielonych kościołach zdarzają się napięcia:

Oni nas chyba za bardzo nie kochają. Ci bracia którzy nam wynajmują ten kościół, widać że stawiają nam jakieś ograniczenia na wiele rożnych sposobów. Np. sprawa choinek oni nam powiedzieli, że nie możemy mieć choinek przy ołtarzu, ponieważ choinki są pogańskie i trzeba było znowu wysłać księdza żeby powiedział, że to jest nasza tradycja i my mu płacimy i też mamy jakieś prawa do tego, więc np. choinki były, ale tylko przez 2 tygodnie i trzeba było wszystko porządnie, solidnie wysprzątać (PLK25).

Dla praktykujących polskich katolików odrębne msze po polsku osłabiają rozwój ich kompetencji językowych. Miejscowe parafie nie zyskują też w nich uczestników życia parafialnego:

Nie chodzę na polskie msze, więc nie znam Polaków (...). Moglibyśmy jednak coś zrobić, żeby się poznać. Na przykład kursy angielskiego, albo coś podobnego. Szkoła, jedno 
miejsce spotkania dla wszystkich, bardzo zbliża ludzi do siebie, możemy też ich uczyć historii po angielsku (IDK70+).

My nie znamy polskiego i to pomnaża izolację między nami. Polacy mogliby lepiej mówić po angielsku, wtedy byliby lepiej zintegrowani z nami (IDK65+).

Irlandzcy parafianie słabo znają polską kulturę oraz prawie w ogóle nie znają osobiście polskich emigrantów. Można nawet dodać, że nie widują się wcale, mimo, że chodzą do tego samego kościoła w niedzielę. Zdanie o Irlandzkich katolikach bywa przy tym dość negatywne, co może wynikać z braku kontaktów:

Widziałem raz jak wychodzą [Irlandczycy] po swojej mszy i tyle (...). Nie widziałem nigdy thumów wychodzących z kościoła. Poza tym Irlandczycy to w niedzielę siedzą więcej w pubach. Chyba nie są pobożni (PDM25).

Brakuje też często kontaktu z irlandzkimi księżmi, co może wskazywać na brak ich aktywności. Irlandzcy duchowni katoliccy zaprosili przecież polskich duszpasterzy i może im się wydawać, że w ten sposób uważają problem posługi dla polskich katolików i ich integracji za rozwiązany:

Tutaj przychodzę na polskie msze. Czasami jednak ktoś z tutejszych księży się pojawiał, ale trudno to zauważyć. A ludzi z irlandzkiej parafii to nie znam, nie widuję ich. Uczestnicy polskich mszy nie spotykają się z irlandzkimi parafianami (PDK34).

Dwoje Irlandczyków podkreśla, że utrudnieniem we wzajemnych kontaktach obu grup jest brak pomieszczeń przeznaczonych na parafialne spotkania:

Brakuje u nas salki parafialnej, gdzie można byłoby wypić kawę czy herbatę, a przy tej okazji się spotkać razem i poznać (...). Potrzeba nam centrum parafialnego, które pomaga w zgromadzeniu ludzi razem ze sobą (IDM65+).

Niektórzy wskazują, że nie zawsze jest możliwe znalezienie kontaktu z Irlandczykami chodzącymi do kościoła:

W kościołach widać głównie starych ludzi i księży. Jeśli są młodzi, to Hindusi, Murzyni, trochę Polaków. Dla mnie irlandzki Kościół to skansen, ludzie przerzuceni z przeszłości, kiedy Kościół pełnił rolę dominującą. Ale i tak lubię pewne elementy, które tu są. Widać większą spontaniczność zachowań, jest Komunia pod dwiema postaciami, księża wychodzą po mszy przed kościół do ludzi (PDK50+).

Ważnym powodem kształtowania różnic w obrębie tego samego Kościoła i wyznania są odmienne przeżycia, przyzwyczajenia, pewne przesądy, wynikające $\mathrm{z}$ religijnego etnocentryzmu Polaków, podtrzymywane przez doświadczenie odmienności religijno-kulturowej na emigracji:

Tu w Irlandii [„,polski” kościół] pomaga przeżywać to, co jest w polskich świętach Wielkanocy i Bożego Narodzenia. Polskie kolędy są wyjątkowe i ładne. Myślę, że mamy wiele do zaproponowania (PDK25). 
Tylko starsi [Irlandczycy] chodzą do kościoła. Dla młodych Irlandczyków ważny stał się pieniądz i Kościoła nie potrzebują. Irlandczycy uważają się jednak za pobożnych, a w Wielki Piątek masowo piją alkohol. Widać tu katolików na pokaz. Jak jest Środa Popielcowa, to chodzą z popiołem na czole (PDK34).

\section{W Anglii zaskoczenie budzą dość opustoszałe kościoły:}

Jak się patrzy tutaj na ilość tych kościołów, jest ich bardzo dużo, nie tylko rzymskokatolickich, i te kościoły pięknie wyglądają z zewnątrz, ale one jakoś pustkami świecą. Nie ma tam nikogo, nic się tam nie dzieje, to jest tylko piękny budynek. Wydaje mi się, że w Polsce to byłoby niedopuszczalne, że jakaś świątynia jest nie użytkowana. Tam byłoby jakieś światło, jakieś nabożeństwo (PLK35+).

Jedna z osób, bywająca dość często na irlandzkich nabożeństwach, negatywnie oceniała religijne zwyczaje irlandzkich katolików:

Kiedy jestem na irlandzkiej mszy, to prawie wszyscy przystępuja do Komunii. Na polskiej mszy Polaków znacznie mniej chodzi do Komunii. Też nie jest to u Irlandczyków dobre, bo chyba zatracili poczucie grzechu. Odbieram to trochę jako lekceważenie (PDM30).

Jednocześnie jednak polscy katolicy nie zawsze oceniają samych siebie jako lepszych:

Polski katolicyzm jest też taki trochę, że jak jedziesz do Polski wszyscy idą do kościoła, wszystkie $30 \%$, a tu idzie $3 \%$. To jest drobna różnica. A myślę, że tutaj ludzie są prawdziwi, którzy naprawdę wierzą, są bardziej religijni niż w Polsce, średnio (PLM31).

Część ludzi przychodzi, by poczuć się wśród swoich, żeby było po polsku - tak myślę. Dla wielu jednak katolicyzm znaczy na emigracji niewiele. Żyją swoim światem i ich tożsamość nie jest związana z katolicyzmem (PDK25).

\section{Tymczasem:}

Powinni ludzie przychodzić do kościoła bo są na obczyźnie, bo są w innym kraju. Powinni się modlić, i powinni przychodzić i dziękować Bogu za pracę, za zdrowie, za rozłąkę którą wytrzymują bez rodzin. Jest to naprawdę ciężko, jest to trudno. Jakoś to nie bardzo mi się to podoba jak przychodzą święta, to ten tydzień przed świętami, parę dni, to ludzi jest dużo, a tak jak przyjdzie normalna zwykła niedziela to, chociaż to dzisiaj jest dość dużo ludzi rano, ale przyjdzie tak jeszcze parę niedziel i będzie 10-15 do 20 osób, więcej już nie ma (PNK45+).

Mimo, że Polacy nieraz wyrażają swoją ,wyższość" religijną, to są też tacy, którzy podkreślają, że katolicyzm polski wcale nie jest lepszy ani szczególny:

Chyba nie, tylko, że w Polsce jeszcze więcej do kościoła ludzi chodzi. Ale robią to też, żeby się pokazać. Więc to jest takie chodzenie na pokaz (...) Nie znam specjalnych różnic. Tu w Irlandii słyszałem o skandalach seksualnych księży. W Polsce księża dużo robią w polityce, widać ich w telewizji (PDM25). 
To nie jest kwestia różnicy polsko-irlandzkiej. Instytucje są ociężałe i tu, i w Polsce. Są zwyczaje religijne, odgrzewanie tego, co ma niby uratować Kościół, ale to są tylko puste formy. W Irlandii próbują robić odnowę przez przestarzałe formy: Legiony Maryi, Rycerzy Kolumba. W tym polski i irlandzki Kościół są podobne. W Irlandii widać, że już wiele osób odeszło od życia kościelnego. W Polsce pewnie to nastąpi, jak ludzie będą bogatsi (PDK50+).

Należy podkreślić, że takie zdanie wyrażają osoby, które dość często i regularnie uczestniczą w kościelnych nabożeństwach. Dla niektórych z nich uboga oprawa irlandzkich nabożeństw ma jednak wartość przyciagającą:

Polubiłam prostotę tutejszych nabożeństw. A co ważne, z księdzem można porozmawiać wychodząc z kościoła, choćby parę słów. Szukałam jednak polskich nabożeństw, bo one są żywsze, bardziej się w nich odnajduję (PDK29).

Jednocześnie porównanie form katolickiej religijności - polskiej, irlandzkiej, brytyjskiej - jest sprawą dość złożoną:

Szczerze mówiąc, jest mi wstyd, ale nie wiem jakie są zwyczaje. Szafarze..., myślę, że nie, mi to jest nie potrzebne, dlatego że jest dobrze tak, jak jest. Ja wychodzę z takiej tradycji gdzie ksiądz zawsze dzierżył władzę i wszystko się musiało odbyć po Bożemu, że tak powiem i jest mi dobrze, nie potrzebuję żadnych unowocześnień. Fajnie by było zorganizować ofiarowanie na mszy świętej, przyniesienie darów pod ołtarz. Może rzeczywiście, może to zaproponuję. Wszystko już jest, jest wizyta duszpasterska, jest nawet ponad program, bo są te wieczorki, kiedy ksiądz przychodzi na tego pączka i kawę - to jest chyba zwyczaj angielski (PLK25).

Irlandczycy są rozśpiewani i rozbawieni, ale nie w kościołach. Dlatego, mimo tradycyjnych pieśni, takich masowych, dobrze znanych, to wydaje mi się, że na polskich mszach jest więcej piękna, muzyki, emocji. Dochodzi do tego wystrój kościołów. Irlandzkie są zgrzebne, z plastikowym kiczem, ale ładnymi murami. Przyciąga surowe piękno kamienia, szpecą świecidełka, groty maryjne itp. W Irlandii jest natomiast lepiej w kontakcie $\mathrm{z}$ księdzem. Mimo że kapłani są starsi wiekiem, to jednak bardziej serdeczni, kontaktowi, nie ma dużego dystansu. Wśród polskich księży, także młodych, także tych tutaj, jest pewna sztywna otoczka. Podkreślają dystans, rolę księdza, jest więcej formalności w kontakcie i załatwianiu spraw (PDK29).

Są też zwyczaje, które Polaków zaskakują na Wyspach Brytyjskich:

Jedyne co mnie zaskoczyło to, w Polsce to nie jest wciąż popularne, ale w Anglii są szafarze świeccy - to są tacy, którzy udzielają Komunii świętej. Nawet ja raz zostałam poproszona o udzielenie Komunii pod postacią wina - ja myślałam, że jestem wtedy tą szafarką - dopiero później się dowiedziałam, że trzeba uzyskać jakąś dyspensę, a ja tego nie zrobiłam, więc nieświadomie uczestniczyłam w tym. To mnie zszokowało, bo w Polsce raczej jeszcze długo tego nie będzie (PLK25).

W świetle badań wyraźnie rysuje się problem braku komunikacji pomiędzy żyjącymi we wzajemnej separacji społecznościami polskich katolików oraz angielskich czy irlandzkich parafii. Nawet w miejscach, gdzie nie ma odrębnych 
budynków sakralnych pomiędzy wskazanymi kohortami etnicznymi tworzy się duży społeczny dystans. Etnicznie zorientowaną religijność Polaków wykazują, zarówno na poziomie instytucjonalnym jak i indywidualnym, tendencje izolacyjne. Trzeba jednak podkreślić, że obecna sytuacja jest całkiem nowa dla parafian i dla duchownych katolickich. Ogromny liczebnie napływ polskich emigrantów jest dla rodzimych Wyspiarzy, a także dla struktur instytucjonalnych Kościoła katolickiego zjawiskiem nowym. Skala zjawiska, a jednocześnie jego dynamizm i płynny charakter nie sprzyjają rozpoznaniu problemów, analizie procesu integracji i wypracowaniu przemyślanych strategii adaptacyjno-integracyjnych.

Zaprezentowane powyżej, wstępnie przeanalizowane wypowiedzi dają nam jedynie pewien wycinkowy obraz całej złożonej sytuacji społecznej, w jakiej żyją polscy katolicy w Irlandii i w Wielkiej Brytanii. Zebrany materiał pozwala na pewne ostrożne uogólnienia, ale przede wszystkim jest szansą oddania głosu samym bohaterom emigracyjnych wojaży. $Z$ pewnością uzyskujemy w ten sposób pewne światło, które powinno skierować dalsze wysiłki badawcze w określonych przez powyższe badaniach kierunkach. Musimy jednak pamiętać o ograniczonej formie i zakresie przeprowadzonych wywiadów i analiz, a zwłaszcza o zagrożeniu, jakie w badaniach jakościowych może płynąć z problemu anegdoty$\mathrm{zmu}^{21}$. Dlatego też na podstawie zaprezentowanych powyżej wypowiedzi nie można w żaden sposób dokonywać uproszczonej generalizacji.

\section{Próba podsumowania}

Wskazaną powyżej wstępną diagnozę sytuacji trudno uznać za negatywną. Emigracja Polaków na dużą skalę do Wielkiej Brytanii i Irlandii jest zjawiskiem bardzo świeżym. Można przypuszczać, że nosi ona charakter tymczasowy, jak twierdzą jedni badacze, albo wahadłowy, jak mówią drudzy. Nie podejmując się głębszego rozstrzygania uwarunkowań zarobkowej emigracji Polaków na początku XXI w., należy podkreślić, że sytuacja, w której znalazła się większość emigrantów jest dla nich na tyle nowa, iż oni sami nie mają ściśle sprecyzowanych planów. Dodatkowo, czynniki takie jak światowy kryzys ekonomiczny (2008-2009) oraz perturbacje integracyjne w ramach Unii Europejskiej, a także dalsza faza polskich transformacji ustrojowych są czynnikami destabilizującymi długofalowe strategie życiowe.

${ }^{21}$ Skłonność do wyboru spektakularnych fragmentów wypowiedzi uzyskanych w wywiadzie trafnie ujmuje m.in. A. B ry m a n: $W$ badaniach jakościowych obserwujemy sktonność do ulegania podejściu anegdotycznemu szczególnie wtedy, gdy tworzone sq wyjaśnienia i wnioski. Pobieżne rozmowy, fragmenty z wywiadów nieustrukturyzowanych (...) stuża jako dowody dla określonego twierdzenia (tezy). Daje to nam podstawy do obaw w przypadku, gdy zastanawiamy się, czy można mówić o reprezentatywności lub ogólności przedstawionych fragmentów materiatu badawczego (A. B r y m a n: Quantity and Quality In Social Research. London: Unwin Hyman 1998 s. 77). 
Trudno zatem mówić w dzisiejszej dobie o konkretnych celach i sieciach migracyjnych. Można zaryzykować stwierdzenie, że lepiej odwoływać się do takich pojęć jak oddolna mobilność na rynku pracy, wzrost średnioterminowej i długoterminowej mobilności przestrzennej społeczeństw rozwiniętych czy nawet - jak powiedziałby Zygmunt Bauman - nomadyzm w epoce płynnej nowoczesności. Dawne rozumienie takich pojęć, jak: emigracja, imigrant, homogeniczność społeczności przyjmującej ulega zatarciu i znacznie się dezaktualizuje.

Ponieważ mamy do czynienia ze słabo jeszcze ukierunkowanym zjawiskiem społecznym, o zróżnicowanej genezie (mimo wyraźnie ekonomicznych motywów decyzyjnych), oraz z płynnością ery intensywnej mobilności społecznej, trudno się dziwić, iż w podejściu praktykujących polskich katolików wydaje się dominować chęć podtrzymywania tego, co znane. Partycypacja w polskich formach religijności daje poczucie bliskości z tym, co świeżo pozostawione $\mathrm{w}$ rodzimym środowisku, albo inaczej patrząc, $\mathrm{z}$ tym, co w Polsce czeka i przyciaga ich z powrotem. Dla osób, które wyraźnie wyrażają chęć powrotu, środowisko kościelne jest jednym $\mathrm{z}$ wymiarów azylu podczas krótkiego (lub względnie krótkiego) epizodu zagranicznej emigracji. Skoro mają możliwość podtrzymywania w polskiej wersji choćby części swoich zwyczajów kulturowych, stylu życia, praktyk religijnych, to nie odczuwają specjalnej potrzeby, by poznawać obce tradycje. Potrzeba swojskości, bliskości kulturowej, łatwości językowych kontaktów wyraźnie wzmaga się w obcym świecie. Nie ma zatem specjalnego powodu, by wyrzekać się kolejnej części własnej tożsamości etniczno-kulturowej, ani szukać form przeżycia religijnego zapośredniczonych w innym języku czy obrzędowości. Z punktu widzenia socjologii kultury obserwujemy dość silny etnocentryzm wśród praktykujących polskich katolików. Swoistą cechą tego etnocentryzmu jest wysoka ocena rodzimej, polskiej formy katolickiej religijności: zwyczajów religijnych, rytuałów kościelnych. Zdaniem wielu respondentów są one bardziej wartościowe - po prostu lepsze - od mdłych bądź nadmiernie zliberalizowanych form katolickiej religijności w Wielkiej Brytanii czy nawet Irlandii.

Wysiłek i potencjał integracyjny odsuwany jest na dalszy plan. Dla wielu respondentów integracja prawdopodobnie pozostawiona zostanie do momentu podjęcia decyzji o dłuższym, co najmniej kilkuletnim, pobycie. Inni uważają, że integracja jest sprawą kolejnego pokolenia. Dzieci polskich rodzin lepiej poznają język i środowisko rówieśnicze. Dzięki temu potencjałowi adaptacyjnemu będą mogły pełniej uczestniczyć w życiu kulturalnym i społeczno-politycznym społeczności przyjmującej.

W świetle tych wstępnych badań jakościowych rysują się tematy warte dalsze eksploracji. Interesującym przedmiotem dalszych badań jest $\mathrm{z}$ pewnością zagadnienie kształtowania się jaźni odzwierciedlonej (Charles H. Cooley) w grupach polskich duszpasterstw katolickich w Wielkiej Brytanii i Irlandii. Do jakie- 
go stopnia wysoka samoocena własnej religijności wiąże się z przynależnością w polskich formach życia religijnego na poziomie publicznym? Wydaje się bowiem, że dla religijnych polskich emigrantów środowisko „polskiego kościoła”, parafii, duszpasterstwa stają się grupa pierwotna, być może przede wszystkim wobec braku innych grup odniesienia oraz niedoborze instytucji o charakterze integracyjnym ze społeczeństwem przyjmującym migrantów lub we własnym etniczno-kulturowym gronie imigracyjnym ${ }^{22}$. Pytania te wiążą się $\mathrm{z}$ problem postaw konformistycznych, ale także z postawą separacji jako strategią akulturacji wśród pierwszego pokolenia emigrantów. Istotną kwestią jest także pomoc ze strony przedstawicieli instytucjonalnej religii, organizacji pozarządowych $i$ agend rządowych w poczuciu tymczasowości życia na emigracji, które towarzyszy polskim emigrantom - czyli „ludziom na huśtawce” ${ }^{23}$. Wskazane powyżej problemy powinny być podejmowane tym dokładniej, im bardziej widoczne staje się, że dla młodego pokolenia Polaków życie i przemieszczanie się w świecie bez granic daje szansę długofalowego rozwoju i pomnaża ich kapitał społeczny i intelektualny.

${ }^{22}$ Por. Ch. H. C o o le y: Social Organization: A Study of the Larger Mind. New York: Charles Scribner's Sons 1909 s. 25-31.

${ }^{23}$ Por. E. J a d ź w i ń s k a, M. O k ó $1 \mathrm{~s} \mathrm{k} \mathrm{i} \mathrm{(red.):} \mathrm{Ludzie} \mathrm{na} \mathrm{huśtawce.} \mathrm{Migracje} \mathrm{między} \mathrm{pery-}$ feriami Polski i Zachodu. Warszawa 2001. 